\title{
Breeding systems in some representatives of the genus Lycium (Solanaceae)
}

\author{
L. MINNE*, J.J. SPIES*广, H.J.T. VENTER* and A.M. VENTER*
}

ABSTRACT

\begin{abstract}
The development of the ovule and the embryo sac of five of the 17 species of Lycium and of one hybrid, recorded for southem Africa, was investigated. All specimens of four of the species and the hybrid (between a hermaphroditic and a functionally dioecious species) were found to be functionally dioecious: they express only one sex, although both male and female organs are present in the same flower. One species was hermaphroditic. The embryo sacs of all species, and of the hybrid. were of the normal eight-nucleate Polygonum type. The structure of the ovary and the development of the embryo sac are similar to those of $L$ e europueum $L$. The absence of unreduced embryo sacs indicates that apomixis does not occur at any ploidy level in the species studied.
\end{abstract}

\section{UITTREKSEL}

\begin{abstract}
Die ontwikkeling van die saadknop en die embriosak van vyf van die 17 Lycium-spesies en van een baster wat in suidelike Afrika aangeteken is, is ondersoek. Daar is bevind dat alle eksemplare van vier van die spesies en die baster (tussen ' $n$ hermafroditiese en " $n$ funksioneel tweehuisige spesie) funksioneel tweehuisig is: hulle gee uitdrukking aan slegs een geslag. hoewel manlike en vroulike organe albei in dieselfde blom teenwoordig is. Een spesie was hernafrodities. Die embriosakke van al die spesies, en van die baster. was van die normale agt-kernige Polygonum-tipe. Die bou van die vrugbeginsel en die ontwikkeling van die embriosak is scortgelyk aan dié van L europaeum L. Die afwesigheid van ongereduseerde embriosakke dui daarop dat apomiksie nie by enige plödievlak by die spesies wat ondersoek is, voorkom nie.
\end{abstract}

\section{INTRODUCTION}

The genus Lycium (Solanaceae) consists of small to large shrubs with a wide distribution in arid to subarid. temperate to subtropical regions of the world (Joubert 1981; Bemardello 1982). The only exceptions, which are more treelike, are $L$. afrum L. and L horridum Thunb. (= L. austrinum Miers) (Palmer \& Pitman 1973). Seventeen Lycium species are known in southem Africa, whereas 50-60 species are found in the western hemisphere (Joubert 1981).

Polyploidy occurs in the genus Lycium (Minne 1992; Spies et al. 1993). As polyploidy and apomixis are often associated (Stebbins 1971), the aim of this research was to determine whether apomixis occurs in the polyploid specimens. The mode of development of the ovule and the type of embryo sac present in $L$ afrum, $L$. arenicolum, $L$ horridum and $L$. tetrandrum was therefore studied.

\section{MATERIALS ANI) METHOIDS}

The material used during this study was collected and fixed in the field. Voucher specimens are housed in the Geo Potts Herbarium, Bloemfontein (BLFU).

Specimens examined /haploid chromosome numbers from Minne (1992) and/or Spies et al. (1993)|

\section{L. afrum $\mathbf{n}=12$}

CAPE:-3318 (Cape Town): Bokbiail. (-CB), A Venter 346, 348 Melkhossurand, R27 road, (-CD), A. Venter 353; Melkbosstrand, Oto du Plessis Ave.. $50 \mathrm{~m}$ north of Dutch Reformed Church on road shoulder. (-CD), A. Venter 371, 373.

\footnotetext{
* Department of Bexany and Genetics. Universily of the Orange Frec State, P.O. Box 339. Bloemfontein 9300.

$\div$ Author to whom comespondence should be addressed.

MS. received 1992-07-13.
}

\section{L. afrum $\times$ L. ferocissimum $\mathbf{n}=\mathbf{1 2}$}

CAPE. 3318 (Cape Town): Melkbosstrand. R27 road. (-CD), A. Venter 352. 355: Melkbosstrand, Otto du Plessis Ave.. $50 \mathrm{~m}$ north of Dutch Reformed Church on road shoulder. (_CD). A. Venter 372.

\section{L. arenicolum $\mathbf{n}=\mathbf{3 6}$}

CAPE.-2824 (Kimberley): on Barkly West road. $6 \mathrm{~km}$ from the Windsonon tumoff to Riverton. (-DA). A. Venter 36/: Kimberley Dist.. Maidavale. on Nooitgedacht ruad. (-DB). Jouber 339-343.

ORANGE FREE STATE.-2825 (Borhof): Modder River bridge on Petrusburg-Kimberley road, (-CD), Jouber 324. 325: Flamink Pan. 5.5 $\mathrm{km}$ west of Modder River bridge on Petrusburg-Kimberley road. (-CD). Joubert 329. 330. 2926 (Bloemfontein): Bloemfontein. University of the Orange Free State Campus, (-AA). Spies 5173.

\section{L. horridum $\mathbf{n}=24$}

CAPE. - 2824 (Kimberley): Maidavale. Kimberley Dist, on Nooigedacht raad. (-DB), Jouben 338: A. Venter 384. $3119^{\circ}$ (Calvinia): $17 \mathrm{~km}$ outside Calvinia on the way to Williston (R27) at the R354 tumoff to Middelpos and Suthertand. (-BD). A. Venter 384.3123 (Victoria West): $7.2 \mathrm{~km}$ from Richmond on N1 to Beaufor West. (-BD). A. Venter 366 : $13.7 \mathrm{~km}$ from Richmond on N1 to Beaufort West. (-BD). A. Venter 368 . 3220 (Sutherland): $25 \mathrm{~km}$ north of Sutherland, (-BC). Jouber 333, 3.34. 3224 (Graaff-Reinet): $102 \mathrm{~km}$ from Uitenhage to Graaff-Reinet. (-DC). Spies $52,34$.

ORANGE FREE STATE_-2825 (Boshof): $1 \mathrm{~km}$ east of Modder River bridge on Petrusburg-Kimberky road. (-CD). H. Venter 9232. 2925 (Jagersfontein): $36 \mathrm{~km}$ from Petrusburg to Kimberley. (-AB). H. Venter 9230.9231.

\section{L. etrandrum $\mathbf{n}=\mathbf{3 6}$}

CAPE. - 3218 (Clanwillam): Lambertshatai heach. (-AB). Spies 5(0)1. $5(0) 2.3318$ (Cape Town): just outside Y zerfontein on R315 road shoulder, (-AC). A. Venser 376; in Yzertiontein on vacant lox. (-AC), A. Venter 377: Bokhasai vicinity. (- (B). A. Vemer 347: Ganzekrabl. (-CB). A. Venter 350, 351, 3420) (Brediackerp): $53 \mathrm{~km}$ from Bredasdorp to Swellendam. (-CA), Spies 5055.

\section{L. villosum $\mathbf{n}=24$}

CAPE - 2824 (Kimberley): $24.7 \mathrm{~km}$ w Barkly West from the Kimberley - Ginckw astad turnoff, (-D)A. Jouben 3/2.3/3. at the Nootgedacht tumoff on the Kimberkey-Riventon road. (-DA). A Venter 388. 384.6.5 

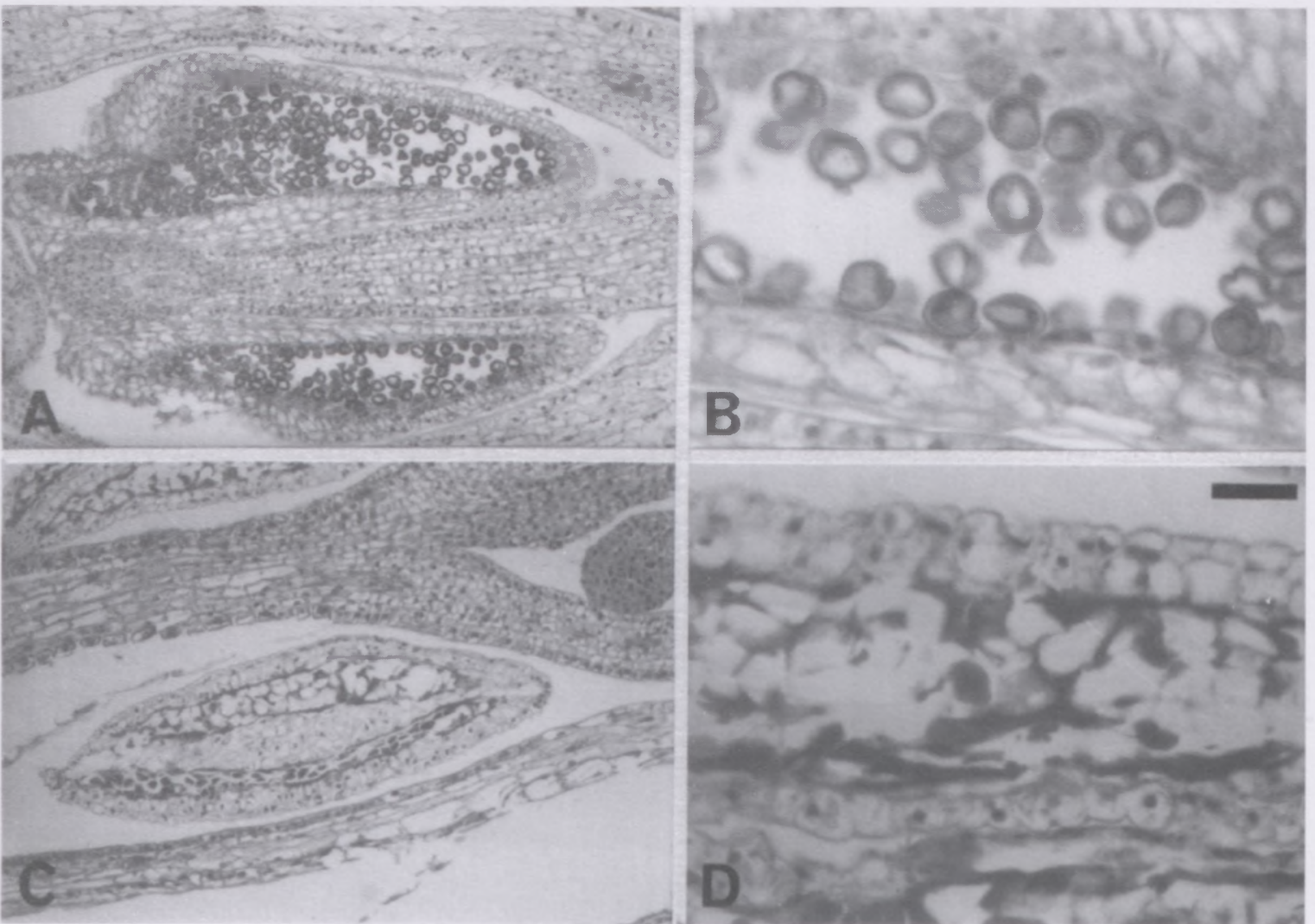

FIGURE 1.-Longitudinal sections through anthers and ovaries of functionally male and female specimens of $L y c i u m$. A, B, L. arenicolum, Joubert 340 , pollen in the functionally male plant; C, D, L. tetrandrum, Spies 5001, pollen in the functionally female plant. Scale bar: A, C, $136 \mu \mathrm{m}$; B, D, $34 \mu \mathrm{m}$.

$\mathrm{km}$ past the Nooitgedacht turnoff on the Kimberley-Barkly West road, (-DA), A. Venter 357; $7 \mathrm{~km}$ past the Nooitgedacht tumoff on the Kimberley-Barkly West road, (-DA), A. Venter $358 ; 8 \mathrm{~km}$ from the turnoff to Riverton on the Kimberley-Windsorton road, (-DA), A. Venter 362 , 363.

The ovules and anthers of flowers of varying ages were fixed in Carnoy's fixative in the field. The fixative was replaced after $24-48$ hours by $70 \%$ ethanol. Dehydration was done in ethanol and tertiary butanol after which the flowers were embedded in pastulated synthetic paraffin wax, sectioned at 5-7 mm and stained with Safranin and Fast Green as described by Spies \& Du Plessis (1986). At least twenty embryo sacs were studied per specimen.

For the scanning electron microscope (SEM) study, flowers were dissected in order to expose the stamens, ovaries and pistils of the specimens. The dissected flowers were mounted on aluminium stubs with the aid of a fast setting glue. The mounted material was then covered with carbon gold (Spurr 1969) for 135 seconds in the Bio Rad SEM coating system. The structure of the pistil, stamen, and pollen of both sexes of the dioecious species were studied with a Jeol Winsem JSM-6400 scanning electron microscope.

\section{RESULTS AND DISCUSSION}

A study of a large number of specimens of Lycium in southern African herbaria, Kew (K), British Museum $(\mathrm{BM})$, Paris $(\mathrm{P})$ and a few other herbaria revealed that all specimens of $L$. arenicolum, $L$. horridum, $L$. tetrandrum

* Studied by A.M. Venter. and $L$ villosum are functionally dioecious*. Such plants express only one sex, although both male and female organs are present in the same flower. In Lycium the term functionally dioecious means the following:

1, functionally male plants have fully developed anthers with seemingly fertile pollen (Figures 1A, B; 2B). Usually two of the stamens of the functionally male plants are included in the corolla tube, whereas two or three are a little exserted. These plants also carry female reproductive organs, but the pistil is underdeveloped and not functional (Figure 2A). The ovule will experience difficulties in receiving pollen, since only a rudimentary style without a stigma may occur on the ovary, or the style and stigma are totally absent (Figure 2A). Occasionally fruit can be found on functionally male plants, but this condition is rare.

2 , in functionally female plants the ovary, style and stigma are normal in structure and slightly exserted from the corolla tube (Figure 2C), whereas the anthers of these flowers are underdeveloped and produce no pollen (Figures IC, D; 2D). Fruit formation is normal. In the hermaphroditic Lycium species every flower bears normal male and female organs.

The ovaries of the Lycium specimens are subsessile, glabrous and have two fused carpels with axile placentation. The base of the ovary is enclosed by a greenish, red, orange or yellow-brown nectar gland. The ovules of both functionally male and functionally female plants are unitegmic, tenuinucellate (Figure 3A, B) and anatropous to hemi-campylotropous. These findings correspond to the 
results obtained by Chiang-Cabrera (1981) on L.europaeum $\mathrm{L}$.

During early stages of development, one cell, lying directly below the nucellar epidermis, differentiates into a primary archesporial cell that is conspicuous by its larger size (Figure 3B), denser-cytoplasmic contents and more prominent nucleus. This archesporial cell gives rise to the primary sporogenous cell, that again forms the macrospore mother cell, which divides meiotically. Usually, a linear tetrad of macrospores is formed in Lycium. The chalazal macrospore develops into a Polygonum type embryo sac that contains an egg cell (Figure 3F), two synergids (Figure $3 \mathrm{C}, \mathrm{G}$ ), two polar nuclei (Figure $3 \mathrm{C}, \mathrm{D}$ ) and three antipodal cells (Figure 3H, I). These findings correspond to the results obtained by Chiang-Cabrera (1981) on $L$. europaeum.

In Lycium the ovules of both the functionally male and functionally female plants have a monosporic eight-nucleate Polygonum type embryo sac. In the functionally male plants the embryo sac is fully developed, although no fertilization takes place because there is no stigma, only an ovary with, at most, a rudimentary style.

Lycium horridum is functionally dioecious, whereas $L$. ferocissimum is hermaphroditic. All the $L$ horridum $\times L$. ferocissimum hybrid specimens examined were functionally dioecious. Therefore, the gene(s) causing functional dioecy is/are dominant over the gene(s) for hermaphroditism.

The embryo sacs of $L$. afrum and the $L$. afrum $\times L$. ferocissimum hybrid are of the normal eight-nucleate $P o$ lygonum type. All the nuclei in the embryo sacs of the studied species and hybrid, are of similar size. In the dioecious $L$. horridum the nuclei of the embryo sac differ in size. In the functionally male plant, all the nuclei are of the same size, but in the functionally female plants, the polar nuclei are much larger than any of the other nuclei. Both the functionally male and functionally female plants of $L$ arenicolum and $L$. tetrandrum have larger polar nuclei than the functionally female plants of $L$. horridum, although these larger nuclei only occurred in one of the two functionally male specimens of $L$ arenicolum examined.

Cytogenetic studies showed that $L$ arenicolum and $L$ tetrandrum display more meiotic abnormalities, such as univalents and bivalents during metaphase, as well as an anaphase bridge in $L$. tetrandrum, than $L$ afrum and $L$. horridum (Minne 1992; Spies et al. 1993). Although polyploidy and meiotic abnormalities occur during microsporogenesis in the anthers of the functionally male plants,
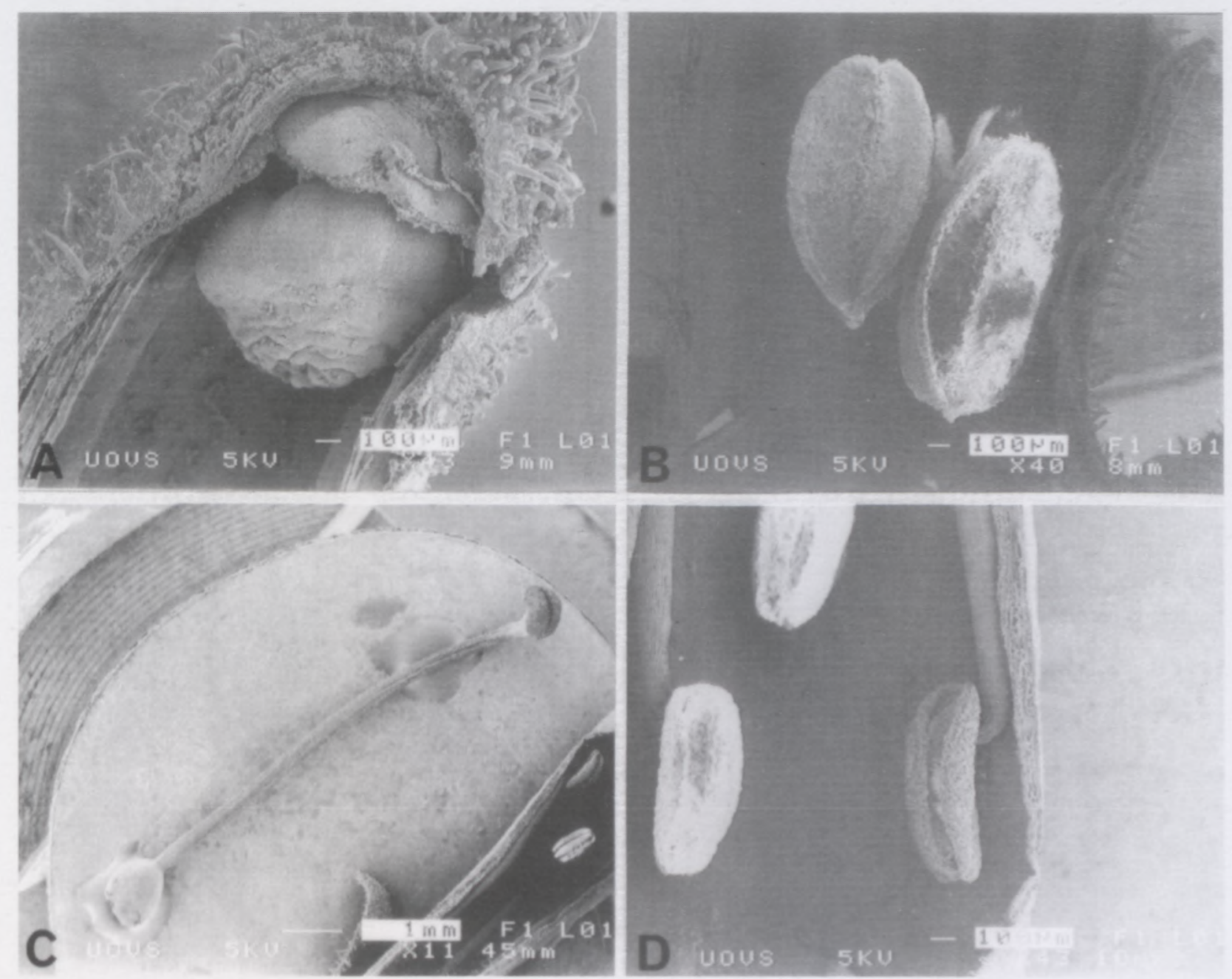

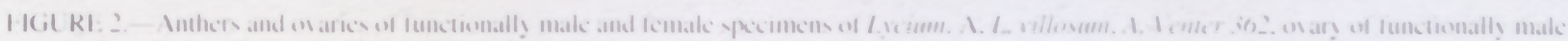
plant; B, L. villosum, A. Venter 362, anthers of functionally male plant; C. L. villosum, A. Venter 358 , pistil of functionally female plant; D. L. villosum, A. Venter 358 , anthers of functionally female plant. Scale bars: A, B, D, $100 \mu \mathrm{m} ; \mathrm{C}, 1 \mathrm{~mm}$. 

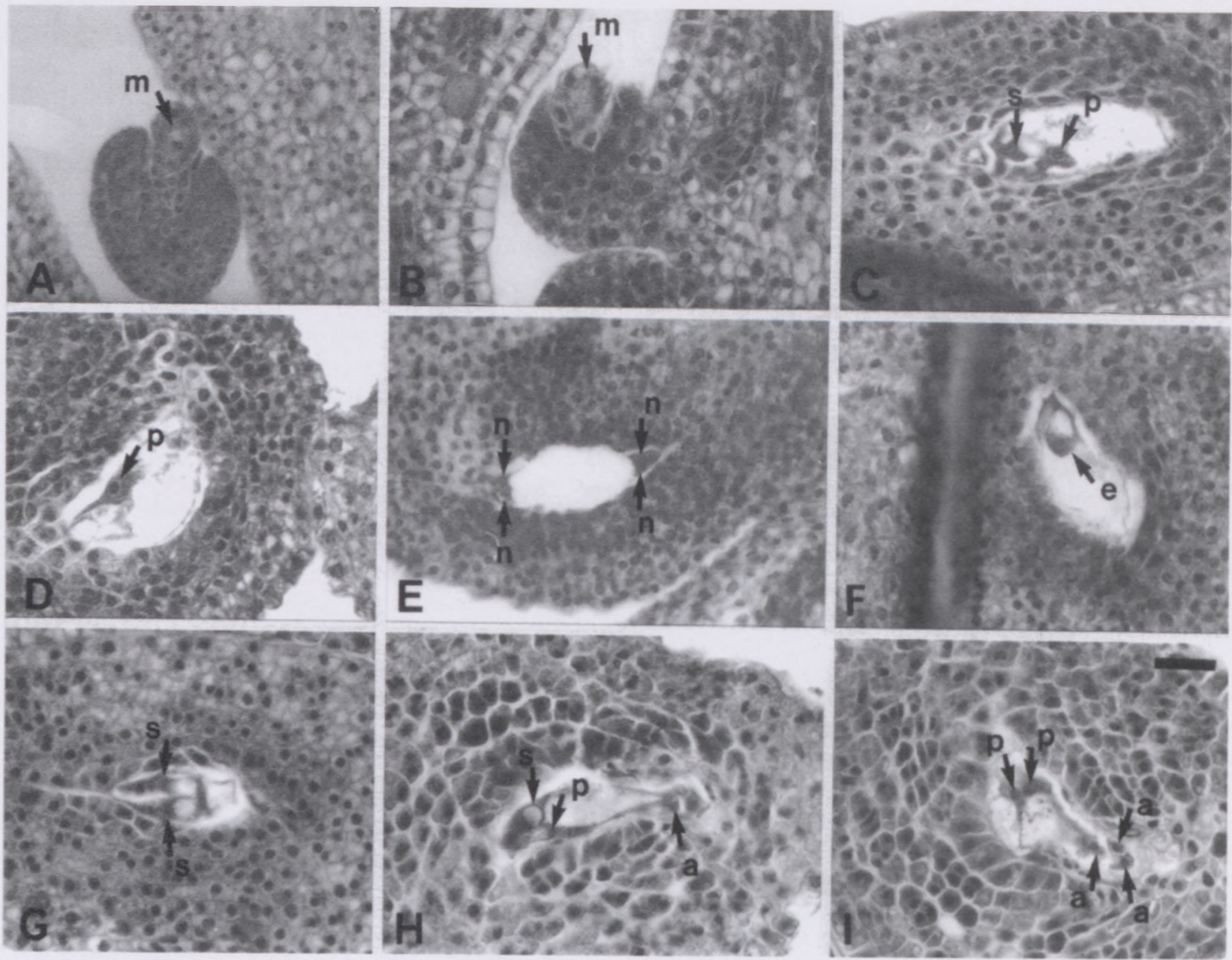

FIGURE 3.-Embryo sac development in some Licium specimens. A, E, F, L. afrum: A, A. Venter 352; E, F, Joubert 346 , B, L. arenicolum, Joubent 340. C, L. horridum, Joubert 334. D, G-I, L. tetrandrum: D, Spies 5001; G, A. Venter 376; H, I, Spies 5055; H, central cell including only one polar nucleus. a, antipodal cell; e, egg cell; m, macrospore mother cell; $n$, nucleus of four nucleate embryo sac; $p$, polar nucleus; $s$, synergid. Scale bar: $34 \mu \mathrm{m}$.

all the functionally female plants have normal embryo sacs (Minne 1992). The pollen of the functionally male plants was fully developed, whereas the pollen in the functionally female plants degenerated.

\section{CONCLUSIONS}

Functionally dioecious species are present in Lycium. All species studied, the hermaphroditic as well as the dioecious ones, have an eight-nucleate Polygonum type of embryo sac. The nuclei of the synergids, egg cell, central cell and antipodal cells were the same size in the hermaphroditic $L$. afrum and the functionally male plants of $L$. horridum. In the functionally female plants of $L$ horridum, the nuclei of the central cell, i.e. the polar nuclei, were larger than the other nuclei of the embryo sac. However, in $L$. arenicolum and $L$ tetrandrum, the polar nuclei of both sexes were larger than the other nuclei of the embryo sac. At all polyploid levels Polygonum type embryo sacs were formed, irrespective of the nature and number of meiotic abnormalities in the anthers. The absence of unreduced embryo sacs indicates that apomixis does not occur at any ploidy level in the species studied. A conspicuous difference in pollen development was also evident. Seemingly viable pollen was found in the functionally male plants, but none in the functionally female plants.

\section{ACKNOWLEDGEMENTS}

We thank the University of the Orange Free State for facilities provided during this study and the Foundation for Research and Development for financial support.

\section{REFERENCES}

BERNARDELLO, L.M. 1982. Estudios en Lycium (Solanaceae). II. Recuentos cromosomicos en entidades Argentinas. Hickenia 1: 321-328.

CHIANG-CABRERA, F. 1981. A taxonomic study of the North American species of Lycium '(Solanaceae). Ph.D. thesis, Department of Botany, University of Texas, Austin.

JOUBERT, A.M. 1981. ' $n$ Taksonomies-morfologiese studie van Lycium in suider-Afrika. M.Sc. thesis, Department of Botany, University of the Orange Free State, Bloemfontein.

MINNE, L. 1992. A biosystematic study of the genus Lycium section Lycium (Solanaceae). M.Sc. thesis, Department of Botany and Genetics, University of the Orange Free State, Bloemfontein.

PALMER, E. \& PITMAN, N. 1973. Trees of southem Africa. Balkema, Cape Town.

SPIES, J.J. \& DU PLESSIS, H. 1986. The genus Rubus in South Africa. III. The occurrence of apomixis and sexuality. South African Joumal of Botany 52: 226-232

SPIES, J.J., MINNE, L., VENTER, H.J.T. \& VENTER, A.M. 1993. A cytogenetic study of the functionally dioecious species in the genus Lycium (Solanaceae). South African Journal of Botany 59: 535-540.

SPURR, A.R. 1969. A low viscosity epoxy resin embedding medium for electron microscopy. Joumal of Ultrastructural Research 26: 3134.

STEBBINS, G.L. 1971. Chromosomal evolution in higher plants. Edward Arnold, London. 